\title{
Policy Research and Analysis Organizations: An Account of Recent Experiences and Some Predicaments in Ethiopia
}

\author{
Mulugeta Abebe ${ }^{1}$
}

\begin{abstract}
Drawing from interviews, archival documents and a range of other sources, this article takes stock of key public policy research and analysis organizations in Ethiopia. It sheds light on the significance of professionalization of policy analysis and its contributions to closing the gap between knowledge and policymaking, offers insights into improved policymaking, hints and lessons for better institutionalization of policy analysis and research. The paper also points to the inauspicious environment in which non-government and university based policy research organizations operate, and touches on the negligible influence that the latter have on policymaking. The central thesis of this article is, therefore, professionalization of policy analysis can achieve a measure of excellence: 1) when there is a permissive environment whereby a given policymaking system permits a constant flow of innovative policy ideas and gives access to policy relevant information; and 2) when the scholars in the policy research institutes maintain standards of objectivity, autonomy and freedom from political partisanship.
\end{abstract}

Keywords: policy research and analysis organizations, policy analysis, bridging the gap between knowledge and policy making, institutionalization of policy analysis, Ethiopia

DOI: https://dx.doi.org/10.4314/ejbe.v6i1.4

\footnotetext{
${ }^{1}$ Associate Professor, Department of Public Administration and Development Management, Addis Ababa University. E-mail: mulugeta.abebe@aau.edu.et or mulugirumw@yahoo.com
} 
Policy Research and Analysis Organizations in Ethiopia

\section{Introduction}

Providing research oriented policy advise to government is a recent phenomena in Ethiopia that might have began with the establishment of the Institute for the Study of Ethiopian Nationalities (ISEN) in 1983. Senior faculty from Addis Ababa University and practitioners from different government institutions staffed the ISEN. In light of the articles provided in the legislation that established it, the ISEN had five thematic programs consisting of Legal and Constitutional Affairs, Administrative Affairs, Economic and Geographic Affairs, Historical and Nationalities Affairs, and Social and Sociological Affairs (Hailu, 2003).

Over the last two decades, however, due partly to the drive for socio-economic development and partly to the generous release of donor money into the industry, the number of policy research institutes in Ethiopia have grown significantly. The impetus for such positive development underscores the importance of professionalization of policy analysis; and in recent times due recognition is also accorded to the institutionalized supply of policy makers with expert advice. Institutionalized policy analysis and government counseling based on practically oriented research do not have a solid tradition in Ethiopia. However, there are signs in the past decade that policymakers have turned to policy researchers seeking for fresh and innovative policy ideas that the experts can generate.

As noted over the past few decades, there are a significant number of policy research institutes that are attempting to make their presence felt among the policy community in Ethiopia. Some are government affiliated research organizations financed by government from state coffin, and nearly all of their projects are funded and supported by a consortium of donors. Others, on the other hand, are operating in an inauspicious environment and live off shoestring budget. The latter are functioning as non-government organizations, and their performance is closely scrutinized in accordance to civil society legislation issued by the government in 2009. A few of the university affiliated policy research institutes appear to command over research capacity and expertise, but remained under-funded, under-resourced and neglected.

It is against this background that this paper attempts to address the following issues:-

1. How active are the policy research organizations in shaping policy decisions? Or how visible are they in the policy making landscape?

EJBE Vol. 6 No. 1/2016 
Policy Research and Analysis Organizations in Ethiopia

2. Do they have the resources, capability and the opportunity to convey their policy ideas to policymakers?

\section{Methodology}

The author, in-person, conducted indepth interviews with the heads of the institutes and/or those that are active in the day-to-day activities of the research organizations under considerations. The interviews were conducted in July and August 2016. The study also closely consulted archival sources and other relevant documents that emphasize the narrative and interpretative approaches to the understanding of the policy research and analysis organizations in Ethiopia. Mogalakwe (2009) argued that documentary research is considered to be as good as, and sometimes even more cost-effective than other social surveys, such as questionnaire and participant observation if used appropriately.

This study, therefore, capitalized on relevant data from archival sources, documents, blogs and pertinent internet sources generated by government institutions, international policy think-tanks and policy research institutes working elsewhere and in Ethiopia. Furthermore, the author perused secondary sources, including books and journal articles helpful in garnering information about the context in which policy research and analysis organizations are operating mostly in developing countries. The descriptions and analyses are qualitative, where opinions ascertained through interviews and secondary sources are pooled together, organized and analyzed. While the available empirical facts offer relatively sufficient evidence to understand the sensitivity of maintaining the balance between the neutrality and objectivity of policy research organizations on the one hand, and influencing policy choices on the other, any study of this sort will always face dearth of data in demonstrating the impact that the former have on policies and the outcomes of implementation.

\section{Structure of the paper}

This article comprises of five sections. This section sets the background, and raises a couple of questions to guide the discussion; and it also highlights data collection methods. Drawing from the theoretical and empirical literatures, the next section sets the stage for subsequent discussions; and it also throws some light on the salient features of policy research organizations, and the various challenges that the latter mostly face in developing countries. Section III discusses the recent experiences of key policy research organizations in Ethiopia. In some detail, this section presents a review of the quality of staff, 
Policy Research and Analysis Organizations in Ethiopia

legal and institutional status, and the part that each plays in influencing policies and practices. It also touches upon the legal, resource and institutional predicaments that policy research organizations have experienced over the years. Section IV appraises the expert potential of policy research and analysis institutes, points to the legal and institutional predicaments that our policy research organizations are dealing with in tandem and separately, and reassess the variations in performance among the research organizations. The last section hints the operational hallmark of policy research organizations, and offers concluding remarks.

\section{The Conceptual Underpinning}

The rationale for research oriented expert advice to policy makers points to the uncertainty and complexity characterizing the public policymaking scene. The uncertain and complex nature of policymaking process, in turn, calls for a group of multidisciplinary scholars with the mandate to carry out practically oriented research who will serve the purpose of improving the quality of policy decisions. In other words, generating research oriented policy options and expert analysis result in professionalization and institutionalization of policy research and analysis. Prior to the recognition of the significance of professionalizing and institutionalizing policy research and analysis, however, politicians and bureaucrats carried out the analysis themselves. Ojagbohunmi (1990) argued that not only does political partisanship dominate policy analyses conducted by government bureaucrats, but the scientific rigor inherent in such analyses are also called into question. More particularly, in relatively closed political systems, objective analysis and critical inputs into the policy making process are often overlooked. This demonstrates the very reason why policy analyses carried out by the bureaucratic arm of government can neither be scientific nor non-partisan (ibid).

Towards the beginning of the 20th century, the predecessors to today's policy research institutes came into being as a response to newly emerging problems in the economy and in national security in West Europe and the USA (Thunert, 2000). During the Cold War, the upsurge of complex social, economic and environmental problems provided the impetus for a new generation of policy research organizations under the rubric of think tanks. It was in the sixties and seventies that the latter extended to include practically oriented research institutes that were not directly concerned with national security (ibid). 
Policy Research and Analysis Organizations in Ethiopia

Situated arms-length from partisan politics, the tradition that have long been cherished in the home lands of think-tanks is that they offer a non-partisan perspective to the policy making scene; and provide research oriented expert advice to policy makers (Dror, 1984, Stone, 2007). The term think tank signifies policy research institutes involved in the research and analysis of particular policy area or a broad range of policy issues, seeking to advise policy makers or inform public debate on policy issues (Stone, 2007: 149). Insulating scholars of policy research institutes from partisan politics is considered as the litmus test of assigning the highest priority to promoting scholarly inquiry as a means to serve better and/or professional policy analysis (Weaver, 1987). According to Dror (1984: 200), think tank is reserved for policy research, design and analysis organizations that are established as enclaves of excellence in which groups of multidisciplinary scholars and professionals work full-time on major policy problems.

Be what it may, policy institutes are usually involved in studying a particular policy area seeking to inform and enlighten policymakers and the public through a variety of channels (Abelson and Carberry, 1998: 529). A policy institute must 'determine what its strategic goals are, who its target audience is over what period of time it seeks to make an impact' (ibid). According to Abelson and Carberry (1980), answers to these questions will help scholars explain how and why policy institutes attempt to exercise both direct and indirect forms of policy influence. They employ a diverse range of channels including books, journals, newsletters, opinion magazines, conference papers, and they also hold open public forums and conferences to discuss key policy issues. According to Myers (1997: 178), few among other important principles that policy research institutes should uphold include independence or autonomy from any particular party, government, or ideological point of view; commitment to neutrality and objectivity with the goal of informing policy choice; commitment to the highest possible quality of staff, research, publications, and dissemination; and cooperation with relevant institutions home and abroad.

Myers noted that 'policy research institutes -autonomous of government yet influential on policy-are important innovations' in building policymaking capacity and enhancing the quality of policymaking (Myers, 1997: 177). In most of the developing countries, policy research and analysis organizations are constituted as non-governmental organizations (NGOs) but some are either semi-governmental agencies or quasi-autonomous units within government. Despite this increasing divergence in legal constitution, the roles and function of 
Policy Research and Analysis Organizations in Ethiopia

such organizations 'put them at the intersection of academia and politics where they aim to make connection between analysis and policymaking' (Stone, 2007).

In the context of developing countries, the commitment to neutrality and objectivity with the goal of informing policy choice and influencing policies and implementation outcomes are a delicate balance to maintain, and it is in fact challenging. In other words, policy research organizations' relationship with policy makers is a very important issue that determines whether or not policy research institutes are making meaningful contributions to policy making. Obviously, the extent to which research output influences policy debates, and influence policies and implementation outcomes very much depends on the nature of that relationship and how the research institutes handle such relationships. The paradox is, therefore, there is a subtle line in this relationship. On the one hand, a research organization might need to be close enough to make meaningful influence on policies and practices; but still far enough to make objective and non-partisan policy analyses, on the other hand (Myers, 1997).

As the argument goes it is not the legal status and structure that determine the influence, but the characteristic of relationship and how the relationship is handled that matter most. In other words, optimizing the relationship between those who offer and who need policy advise is the hallmark of policy research and analysis organizations. For instance, Thailand Development Research Institute (TDRI) is a private foundation and has not risked of being ignored by policymakers essentially because it had senior government officials and influential leaders from the private sector on its board (ibid). Furthermore, although the Bolivian Social Policy Analysis Unit (UDAPSO) was a government agency serving under the Ministry of Human Development, the directors of the institute defended its autonomy so much so that it was influential among policymaking circles in Bolivia (Myers, 1997: 182). Not only did the neutrality and objectivity that both TDRI and UDAPSO promote earned them reputation at home and abroad, but they also survived changes in government and parties.

In common parlance, however, doing policy research for the purpose of promoting, informing and improving policy options continues to be a challenging enterprise in developing countries. Creating and maintaining a stable source of funding that serves to create and provide incentives that balance rewards for quality research is one area of sticky situation. In other words, retaining high quality research staff, producing high quality work, and maintaining influence on policy over a long period of time is biggest challenge (Myers, 1997). Stone (2007) further noted that the ability of policy research and 
Policy Research and Analysis Organizations in Ethiopia

analysis organizations to have an effective presence among policy-making communities is influenced not only by institutional and cultural elements, but also by economic considerations. Establishing close and enduring relationships with key policy makers, taking part in long-term research projects, and to promote their visibility and relevance in the policy making process, policy research and analysis institutes need stable funding (ibid). In reality, however, policy research and analysis organizations almost always run the risk of financial uncertainty.

The most serious challenge, what has come to be known as extensional threat to policy research and analysis organizations, stems from institutional and legal establishments. This is due chiefly to certain features of the political system. The fusion of power between the executive and the parliament, as is the case in most developing countries, does not allow policy research experts multiple access points to policy makers and policy relevant information. In other words, the nature of the political system is such that it allows policy decisions to concentrate in the executive (Abelson and Carberry,1998). Second, the political system might work as a disincentive to policy researchers; and as a result, the party unity and discipline that accompany it makes it difficult for independence of individual members of parliament to seek advice from policy researchers (ibid). This is essentially because party politics and discipline dictates the relationship between the MPs and the political leadership. As a result, avenues for policy research organizations to forge any alliance with individual members of parliament is limited. Moreover, since party leadership can draw party and government resources to generate their own policy research, there may be less demand and incentive for independent, non-partisan policy expertise (Abelson and Carberry,1998). Still worse research institutes are informally co-opted and/or are compelled to conform to strictures of state monitoring and censorship.

\section{The recent experiences of key policy research and analysis organizations in Ethiopia}

Drawing from interviews conducted with heads of key research institutes, and a range of other sources, this section discusses the achievements and pitfalls that the key policy research and analysis organizations in Ethiopia have experienced for nearly a decade-and-half. In order to make sound judgment on performances and deficits, among other issues, the study focuses on the extent to which their presence is being felt in the public policy making process and their role in shaping policy ideas, their academic and/or professional influence, and legal and institutional context in which policy research organizations operate.

EJBE Vol. 6 No. 1/2016

Page 78 
Policy Research and Analysis Organizations in Ethiopia

\section{Ethiopian Economic Association (EEA)}

Academics and practitioners living mainly in Addis Ababa established Ethiopian Economic Association (EEA) in 1991. Ethiopian Economic Association (EEA) articulated a vision to become a non-partisan, independent and non-profit economic policy research and analysis organization dedicated to economic policy analysis and inform policy debates on Ethiopian economy. With the establishment of its research wing-Ethiopian Economic Policy Research Institute (EEPRI)-in 2000, the research and dissemination work on a range of economic policy problems and issues were even more promoted. Over the past decade-and-half, EEA/EEPRI produced abundant annual research reports, peer reviewed journal articles, books, conference proceedings, working papers, monographs ...etc. For well over a decade, very many workshops, national and international conferences, round table discussions, economic policy dialogue forums have also been conducted. It has, therefore, established itself as a policy research and analysis organization making direct or indirect influence on policymaking. As a result, its reputation as a repository of economics experts resonated at home and abroad. EEA/EEPRI has built its own multi-purpose premise that housed donor funded research projects and has also put in place relatively well organized system of research management.

As a membership based association, EEA's general assembly designates an executive committee consisting of nine members drawn from the former to provide leadership. Elected by the general assembly, the president of the association presides over the leadership activities of EEA. Over the past few years, however, EEA/EEPRI has continually been facing legal and regulatory hurdles that disrupted its policy research and analysis work.

In the wake of EEPRI, EEA distinguished itself as an economics policy and research analysis institute that mustered the resources and expertise that the country ever had in the discipline. In terms of a series of policy dialogue forums, publications and disseminations, its presence has also been widely felt among academics, practitioners and the policy community in the country. Especially, in the early stage of its establishment, multilateral and bilateral donors financed both supply and demand driven research projects; and as a result, EEA/EEPRI's recognition radiated both at home and abroad (EEA, 2015). 
Policy Research and Analysis Organizations in Ethiopia

\section{Table 1. Establishment, size and quality and composition of staff, legal and institutional status of policy research organizations}

\begin{tabular}{|c|c|c|c|c|c|c|c|c|}
\hline \multirow[t]{2}{*}{ Institute } & \multirow{2}{*}{$\begin{array}{c}\text { Date } \\
\text { founded }\end{array}$} & \multicolumn{2}{|c|}{ Staff } & \multirow{2}{*}{$\begin{array}{c}\text { Recurrent } \\
\text { budget } \\
2015 / 16 \\
\text { (2008 E.C) } \\
\text { in millions } \\
\text { (Birr) }\end{array}$} & \multirow{2}{*}{$\begin{array}{l}\text { Research } \\
\text { programs }\end{array}$} & \multirow{2}{*}{$\begin{array}{c}\text { Staff } \\
\text { composition }\end{array}$} & \multirow[t]{2}{*}{ Legal status } & \multirow{2}{*}{$\begin{array}{c}\text { Directors/ } \\
\text { Heads } \\
\text { since } \\
\text { establish } \\
\text { ment }\end{array}$} \\
\hline & & $\begin{array}{l}\text { MA/ } \\
\text { MSc }\end{array}$ & $\mathrm{PhD}$ & & & & & \\
\hline $\begin{array}{l}\text { EEA/ } \\
\text { EEPRI }\end{array}$ & 1991 & 5 & 4 & 3.7 & 4 & Economists & $\begin{array}{c}\text { Ethiopian } \\
\text { Residence } \\
\text { Charity } \\
\end{array}$ & 4 \\
\hline FSS & 1998 & & None & 2.3 & none & $\begin{array}{l}\text { Multidiscipli } \\
\text { nary }\end{array}$ & $\begin{array}{c}\text { Ethiopian } \\
\text { Residence } \\
\text { Charity } \\
\end{array}$ & 3 \\
\hline EDRI & 1999 & & $12+$ & 11.2 & 6 & Economists & $\begin{array}{c}\text { Semi- } \\
\text { autonomous } \\
\text { Govt. Agency }\end{array}$ & 1 \\
\hline IDPR & 2014 & 3 & 6 & 1.7 & 9 & $\begin{array}{c}\text { Multidiscipli } \\
\text { nary }\end{array}$ & $\begin{array}{c}\text { Affiliated to } \\
\text { AAU }\end{array}$ & 2 \\
\hline
\end{tabular}

\section{Source: own survey}

Currently, EEA/EEPRI carries out research on four major thematic programs, namely, macro-economy, poverty and human resources, trade and industry, and agricultural and natural resources. There is a limited contingent of permanently employed research staff consisting of four PhD and five junior researchers with MSc. However, there is a significant pool of quality research expertise within the active members. EEA/EEPRI, therefore, draws its researchers from members for it is expensive to maintain payroll and other expenditures associated with hiring permanently employed researchers. Since 2011, EEA/EEPRI has carried out fifty-five researches on a range of Ethiopian economic policy and development issues (EEA, 2016: 6). Out of these while fifteen were core researches, thirty researches were commissioned through collaborative arrangements involving a consortium of donors and EEA (EEA, 2016). The Annual Report on the Ethiopian Economy that delves into the macroeconomic and sectoral economic problems and issues is the most important work that EEA/EEPRI has been identified with. EEA is currently operating as a residence charity under the Proclamation No. 621/2009.

\section{Forum for Social Studies (FSS)}

Senior academics from Addis Ababa University established Forum for Social Studies (FSS) in 1998. Its founders envisioned FSS as an independent, non-profit 
Policy Research and Analysis Organizations in Ethiopia

and non-partisan policy research organization dedicated to practically oriented policy research and the promotion of public dialogues on a broad range of policy issues and problems. FSS' by laws and visions enshrine its commitment to neutrality and objectivity with the objective of informing policy choices, but refrain from advocating any particular ideology or choice. Since its establishment in the late 1990s, FSS has earned the reputation of engaging policy makers in discussion forums on social and development policy issues such as education, health, gender, environment, poverty ... etc. For over one-and-half decades, it has published policy briefs, periodicals, research reports, monographs, books ... etc. Currently, FSS is registered as an Ethiopian resident charity under proclamation No. 621/2009. While FSS is a membership organization, its researches and publications are financed by a consortium of donors. A general assembly meets annually and nominates a nine member advisory board. The latter appoints executive director for four years to run and oversee the day-to-day activities of the institute. It has seen three executive directors since its establishment.

Unlike its counterparts, FSS opts not to commit itself to a set of thematic research programs. Drawing research expertise from active members, it holds regular policy dialogue forums on a wide range of social and economic development problems and issues. For instance, FSS conducted nine different policy dialogue forums and four dissemination workshops in the year 2015/16. In the early years of its establishment, senior government officials and high profile public technocrats participated in the dialogue forums both as presenters and participants. Over the last decade, however, most participants come from academic community, middle level government officials, the private sector and the NGOs. Due mainly to the absence of stable funding, FSS prefers employing contract researchers from among its members. FSS, however, has a contingent of permanent staff whose responsibilities are limited to developing project proposals, and writing terms of references to guide the work of contract experts who are being hired for a specific period of time. Sponsored and funded by USAID, DEFID, Civil Society Support Program (CSSP) and European donors, FSS harbors a few commissioned research projects on health, education, environment and poverty.

\section{Ethiopian Development Research Institute (EDRI)}

Established in 1999, the Ethiopian Development Research Institute (EDRI) is a government affiliated policy research organization authorized by government to carryout research on a range of economic development problems and issues in 
Policy Research and Analysis Organizations in Ethiopia

the country. EDRI has seven government ministers as well as senior government officials on its advisory board with the Director of the Institute as ex-officio member. The latter is a senior and long serving government technocrat ${ }^{2}$, who is also a chief economic advisor to the Prime Minister of Ethiopia. Due partly to the generous donor funding such as African Capacity Building Foundation $(\mathrm{ACBF})$ and partly to the legitimacy and support that it enjoys from government, it has managed to attract qualified and aptly educated research staff and contract researchers from local sources. Evaluated in terms of research staff and quality of research output, EDRI was ranked as the top public policy research organization in the country in 2015 by the US based Think Tanks and Civil Societies Program (TTCSP) (McGann, 2015). EDRI consists of six major research units, and each research center presides over several programs that reflect respective units and fields. The institute has also housed a significant number of research programs and projects that are being funded by various international and multi-lateral organizations and the UN system.

In the first few years of its establishment, EDRI started to work in the prime minister's office with a limited contingent of staff, and employed contract researchers mainly drawn from Addis University. Initially, African Capacity Building Foundation (ACBF) provided core research funding to finance research projects, and $\mathrm{ACBF}$ has continued to do so.

Located inside the heart of government, EDRI serves as high level policy research and analysis unit working very closely with senior government officials and cabinet ministers. Not only does this very position allow the institute command significant influence on policy decisions, this has also opened ample opportunities for the Institute to get access to policy relevant information useful for policy analysis. Over the years, capitalizing on the largesse of donor support, the Institute has made extraordinary effort in building research expertise. As a result, it has currently twenty $\mathrm{PhD}$ research staff, and eight of them are drawn from different institutions of higher learning working with the Institute as contract researchers. EDRI sent most of its twelve researchers abroad (mostly to Europe) and received advanced education in economics. Over the past decade EDRI has, therefore, built a repository of relatively well educated and qualified research expertise.

\footnotetext{
${ }^{2}$ A few weeks after submission of this work for review and publication, the author has learned that a new director has taken over EDRI's leadership.
} 
Policy Research and Analysis Organizations in Ethiopia

Institute of Development and Policy Research (IDPR)

Several years after the Institute of Development Research (IDR) was dissolved, Institute of Development and Policy Research (IDPR) was set up in March 2014 under the auspices of Vice President for Research and Technology Transfer of Addis Ababa University. Drawing nine faculty from three colleges, namely, Colleges of Business and Economics, Development Studies and Social Sciences into its advisory board, IDPR has instituted its system of governance. IDPR seems to draw its inspiration from a vision to be 'a center of excellence dedicated to generating evidence based knowledge that influence policymaking thereby contributing to the development goals of the country' (Tegegne, 2016). Although it is only two years since its establishment, the institute has shown remarkable performance in attracting a significant number of donor funded research projects. Moreover, it conducted monthly seminars in which senior government officials, experts from multilateral organizations and academics from Addis Ababa University addressed a range of policy and development issues in their lectures in the year 2015/16. The composition of IDPR's research staff is fairly multi-disciplinary involving seven $\mathrm{PhDs}$ and three with MScs/M.As. Appointed by the University, the institute's day-to-day activities are run by a director and a few support staff.

\section{Potential and some predicaments}

Generally, in terms of size, resources, and the leverage to convey policy ideas to policy makers; there is considerable diversity among policy research institutes in Ethiopia.

EDRI, for instance, has a senior government official serving as the head of the institute. Not only is the executive director appointed by the prime minister and is accountable to him, over the past decade and half, he has also served as an important channel for research funding. The director has also a strong network of relationship both with government and donors. He has, therefore, created confidence among government circles that they have someone who understands government priorities, policies and programs at the helm of the policy institute.

As part of its close engagement with policy makers, EDRI has been holding Friday seminars for over a year involving relevant middle level government experts representing different government ministries and agencies. Sixteen such seminars having so far been conducted, the participants have benefited from discussions in which various experts come as paper presenters. EDRI also 
Policy Research and Analysis Organizations in Ethiopia

conducts a high level forum involving senior government officials at least twice in a year. This forum brings the best local and expatriate experts to converse with senior government authorities. The forum is, however, not open for public discussion. As noted, the core research staff are holding $\mathrm{PhD}$, and five among them did their post-doc that helped them build quality research expertise in the Institute. Moreover, the EDRI's research experts regularly prepare and issue policy notes on various economic development matters to inform policymakers, which might have influenced policymakers directly or indirectly. Moreover, the Institute delivers annual performance reports both to the executive and to the parliament. Government allocated a recurrent budget amounting 11.2 million Birr in 2015/16 for EDRI.

Over almost a decade, EDRI has made its presence felt both among the policy and academic communities through its various publications and blogs on its website. Peer reviewed working paper series which has been published for more than 6 years, policy-research brief (for a wider audience) with the language and wording understandable to the general public, annual report on Ethiopian Economy, just to mention a few among other publications issued by EDRI. The Institute encourages its staff to publish on academic journals that have earned international recognition, and participate in national and international conferences as paper presenters and speakers. In 2015/16, for instance, nearly a dozen of its staff participated in international conferences organized by World Agricultural Conference, World Bank, and International Growth Center and South Africa.

While EEA/EEPRI and FSS are registered as residence charities under the Ethiopian law, IDPR is affiliated to the oldest institution of higher learning in Ethiopia, i.e., Addis Ababa University. This situation permitted them to enjoy a measure of functional autonomy and research freedom. Over the years, however, not only have they little access to policy relevant information generated by government, but their research outputs also make much less influence on policy makers.

Furthermore, due partly to the absence of stable finance and partly to the legal restrictions that impose limits to their functions, EEA/EEPRI, IDPR and FSS' effort to be involved in long term research and influence as well as inform public policy decisions and policy debates in Ethiopia are being hampered. While they all deserve credit for shaping policy discourse in this country, these research and analysis institutes may not be effective in making direct impact in terms of shaping policy decisions. The predisposition to make direct influence on policy 
Policy Research and Analysis Organizations in Ethiopia

making and the aspiration to play a more meaningful role as policy research and analysis organizations might hinge on the nature of the policymaking system.

Government affiliated policy research and analysis institutes such as EDRI have, on the other hand, the privilege of making direct access to policymakers, and senior government officials are also serving as the heads of the institutes. As noted, the leadership can provide prestige, and makes it possible for easy access to policy relevant information. Research freedom that has a bearing upon critical policy analysis is perhaps less likely to be guaranteed. Moreover, more often than not, the pre-conceived ideology of government set the parameter for thinking and action in policy analysis. A policy institute's charge to question the status quo and to think the unthinkable might trigger skepticism among party and government circles as has particularly been experienced by FSS and EEA. This tendency might even deter policy experts from offering fresh insights, deeper analysis and innovative alternative policy choices on a wide range of development programs and policies. Moreover, since party leadership can draw party and government resources in generating their own policy research, there tends to be less demand and incentive for independent, non-partisan policy expertise in Ethiopia.

\section{Concluding remarks}

As the foregoing discussion demonstrated, the legal basis that allows a policy institute a degree of certainty, prestige, independence and critiques of existing policies to government have imposed limits on the activities of the researchers in Ethiopia. Additionally, almost all of the policy research and analysis organizations have not instituted monitoring and evaluation mechanisms to help them attest that they are making meaningful influence on policy choices and implementation outcomes. In other words, the policy research and analysis organizations have rarely carried out assessments to determine the impact that their analyses and advises have on policy choices and implementation outcomes. Furthermore, as the discussions unraveled, while the government affiliated institutes seem to lend intellectual credibility to state policies, the nongovernment ones are struggling to overcome institutional, legal and resource barriers thereby casting a shadow on their ability to make meaningful influence on policymaking.

At stake, therefore, is the survival of policy research and analysis institutes that are operating as non-government entities, although there is a huge expert potential in them. In fact, some of the non-government and university based research organizations are informally incorporated or co-opted into government 
Policy Research and Analysis Organizations in Ethiopia

sponsored policy development. In all, while the non-government policy research and analysis institutes and university based research organizations are grappling with the strictures of state control, the government affiliated ones appear to have enjoyed a great deal of legitimacy and access to policy relevant data that have a bearing on policy analyses. In effect, therefore, the standards of research and integrity of policy analyses that the variety of research organizations offer in this country can be called into question. 
Policy Research and Analysis Organizations in Ethiopia

\section{References}

Abelson, E and Carberry, C. (1998). Following Suit or Falling Behind? A Comparative Analysis of Think Tanks in Canada and the United States. Canadian Journal of Political Science, Vol. 31 (3): 525-555.

Dror, Y. (1984). Required Breakthrough in Think Tanks. Policy Studies Journal: September, Vol. 16:199-225.

Ethiopian Economic Association (EEA) September 2015. Annual Performance Report: July 1, 2015-June 30, 2016. Addis Ababa, Ethiopia.

Ethiopian Economic Association (EEA), January 2016. Strategic Plan (2015/16-2019/20). Addis Ababa, Ethiopia.

Federal Democratic Republic of Ethiopia, 2009: Proclamation No. 621/2009. Addis Ababa, Ethiopia.

Hailu Wolde Amanuel. (2003). The Institute of Ethiopian Nationalities: Establishments and Accomplishments. The XVth International Conference on Ethiopian Studies. Hamburg, Germany.

McGann, J. 2015. Global Go To Think Tank Index Report. University of Pennsylvania: Think Tanks and Civil Societies Program (TTCSP).

Mogalakwe, M. (2009). The documentary research method - Using documentary sources in social research. Eastern Africa Social Science Research Review, Vol. 25, No. 1: 43-68.

Myers, C. (1997). Policy Research Institutes in Developing Countries. In Grindle, M, (Eds). Getting Good Government: Capacity Building in the Public Sectors of Developing Countries. Harvard Institute for International Development: Harvard University Press.

Ojagbohunmi, G. (1990). Institutionalization of Policy Analysis in Developing Countries, with Special Reference to Nigeria. Institute of Social Studies (ISS), the Hague, the Netherlands.

Stone, D. (2007). Public Policy Analysis and Think Tanks. In Fischer, F; Miller, G and Sidney, M (Eds). Handbook of Public Policy Analysis: Theory, Politics and Methods. New York: CRC Press.

Tegegne G/Egziabher, (2016). Exit Report on the Institute of Development and Policy Research (unpublished report). (IDPR).

Thunert, M. (2000). Think Tanks in Germany. Deutschland: No. 3: June/July.

Weaver, K. (1989). The Changing World of Think Tank. Political Science and Politics. Vol. 22 (3): 563-578. 